\title{
Canada's HIV blood inquiry turns poisonous
}

Montreal. Lawyers representing Canada's Liberal federal government have launched a fierce attack on an inquiry set up by its Progressive Conservative predecessor into the country's system of blood distribution, just as the inquiry is entering its final stage.

And internal changes being introduced by the Canadian Red Cross in advance of the inquiry's report have been criticized for reducing the influence of physicians on the way the system is run.

The inquiry, headed by $\mathrm{Mr}$ Justice Horace Krever, is seeking to allocate blame for the infection of some 1,200 Canadians with the human immunodeficiency virus (HIV) and another 12,000 with hepatitis C through contaminated blood and blood products (see Nature 379, 663; 1996)

Together with the Red Cross - as well as various provinces, pharmaceutical companies and individuals - the government has already appealed to the courts to limit Krever's conclusions, and has denied him access to some documents he requested. It has also set up a task force to submit a plan by 15 February to remodel the federal blood system - pre-empting Krever's report, which is not due until the end of April.

In a new twist, the federal government has now accused Krever of looking for scapegoats rather than focusing on improvements to the blood distribution system, and has called his potential findings of misconduct against bureaucrats "repugnant" and "without foundation".

The charges are contained in the government's final submission to the inquiry. But
David Dingwall, the health minister, promptly dissociated himself, the government and the justice minister from its "inflammatory language" - which he blamed on lawyers in the justice department.

This was followed by an apology to Krever from the federal government lawyer, Donald Rennie, who admitted that the language of the government's submission could be interpreted as impugning the judge's reputation and that of his inquiry - although denying that this had been its intention.

The Canadian Red Cross, in its own final submission to the inquiry commission, says that individuals or institutions should not be blamed for what happened because those involved, "without exception, were doing the best they could". Yet in the same submission it argues that the federal Canadian Blood Agency was responsible for a delay in implementing HIV testing of the blood supply, for which the Red Cross has been blamed.

Without waiting for the recommendations of either the commission or the government task force, the Red Cross has already made far-reaching changes in its internal organization. But these have been controversial. Fundamental differences of opinion between physicians and bureaucrats have led to the departure of about a third of the agency's physicians, and others are known to be dissatisfied.

One of those who have left in protest is Bert Aye, former director of Red Cross national blood services. Aye says that he could not support the changes, either morally or professionally. "The Red Cross has systematically removed all physicians who were in charge of blood centres including the national director - and replaced them with lay managers," he says.

Aye argues that it is the physicians who continue to bear responsibility for maintaining the safety and quality of blood supplies. "The authority and role of the physicians in the new structure remain ambiguous, yet their responsibility and accountability remain well defined. What will happen if and when another crisis appears such as that of HIV?" he asks. "Who will take responsibility? A committee?"

The Red Cross's reorganization seems to imply that the blood contamination was the fault of doctors, says Aye, and that replacing them with laypeople should rectify the problem. But, he says, laymen do not have the technical expertise to make the system safer. In fact, as new and more complex biotechnological procedures are being adopted, he says, the need for closer involvement of physicians increases .

Aye fears that current plans for reshaping blood systems in Canada and other countries would not improve the safety of the blood supply or reduce the impact of future crises. "Most of the management reviews in Canada, the United States and the United Kingdom have been done either with the objective of containing costs or to improve regulatory compliance," he says. "These are limited objectives and, if continued, will mean that blood centres will no longer be able to attract the kind of professionals required."

David Spurgeon

\section{'Ban tourists' call to save glacier source of the Ganges}

New Delhi. The Gangotri glacier in the Himalayas, the source of the river Ganges, is threatened by tourist traffic, adventure sports and pilgrims visiting nearby shrines, say Indian glaciologists. They want a ban on human activities that they believe accelerate the process of weathering of the glacier, which has shrunk by 600 metres since 1935 .

"Massive cracks have developed in its lower reaches," says Syed Iqbal Husnain, a professor in the department of environmental sciences at Jawaharlal Nehru University in New Delhi. Husnain led an expedition to the glacier recently and found that about 3 square kilometres of ice had collapsed.

Husnain runs the Himalayan glaciers project, funded by India's science ministry, and also heads the Asian chapter of the International Commission for Snow and Ice. He says his team found "glaring changes" in Gangotri since his last survey in 1991. "There are huge blocks of dead ice covered by debris completely detached from the main body and the snout has virtually collapsed." All Himalayan glaciers are receding, but at Gangotri human intervention and environmental degradation are making the problem worse, he says.

A lush green valley at Topoban has become an attraction for tourists and trekkers, who must cross the glacier to reach it. The glacier is popular with package tours as it is easily approachable. "Each year half a million pilgrims visit a Hindu shrine $15 \mathrm{~km}$ down below," says $D$. N. Tankha, director of Gangotri Conservation Group, a voluntary organization. Last year 20,000 pilgrims continued on to the glacier.

As a result the place is littered with plastic bags, tins and other debris. Husnain counted over 70 'dabhas' or roadside eating places - one close to the glacier's snout which burn wood and kerosene, releasing smoke and carbon dioxide. Wood burning has led to massive felling of trees.

One likely consequence is change in the microclimate in the region around the

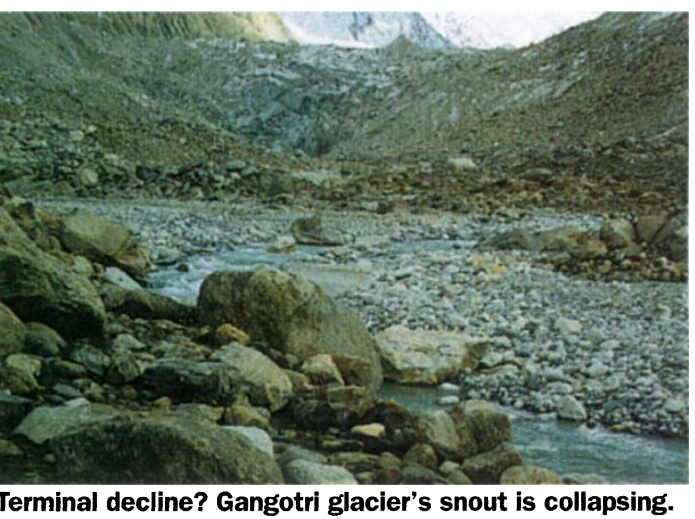

glacier, say scientists at the university. They are hoping for funds to set up a network of electronic stations to relay weather and pollution data from the area. "The environmental damage can be seen with naked eyes but needs to be studied in detail with instruments," says Husnain. A proposal to establish a Himalayan development authority is already before the Indian cabinet.
K. S. Jayaraman 